\title{
Further Experimental Studies on the Function of the Pineal Body.
}

\author{
By \\ Dr. Yositame Izawa. \\ (Fram the Anatomical Laboratory of the Okayama Mcalical School, Okayama Japan.) \\ Six Plates.
}

The pineal body was for a long time looked upon as a functionless remnant and from a phylogenetical point of view was accepted as a rudiment of the third eye, which is, at the present time, only found in hatteria punctata. As far as is known an epiphysis is present in all vertebrates with the exception of mixinoids and crocodilia. In man the pineal body is pear shaped, lies just beneath the splenium of the corpus callosum resting upon the corpora quadrigemina. The gland varies in size shape and pigmentations and does not stand in any proportional relation in the size of the brain or the size of the body.

According to UEmura ${ }^{1}$, the average weight of the human pineal body is $0.157 \mathrm{~g}$. and it measures $0.84 \mathrm{Cm}$. in length, $0.63 \mathrm{Cm}$. in breadth, and $0.42 \mathrm{Cm}$. in thickness. In mammal its size shows considerable variability, although in general cone shaped. Embryologicaly the gland is derived from a separate and distinct evagination of the roof of the third ventricle. A great quantity of literature upon the histological studies of the pineal body is found, and there is quite an abundance of knowledge on the histological structure of the gland, viz. parenchym cell, neuroglia, connective tissue and nerve fibers. And as far as the structure is concerned,

1) L'enuli. S., Frankfurt. Zeitschr. f. Path., Bd. 이, 191\%. 
the cells bear a very close resemblance to the secreting gland cell ${ }^{1}$. The writer is not concerned here with the problem of its origin or structure but with that of function. Disturbances of function by tumor during the prepuberal period give rise to pineal disorder, namely, premature development of primary and secondary sexual characters. Experimental removal of the pineal body has been reported by several workers; but pinealectomy has been handicapped by the anatomical location which makes its complete removal very difficult. In the previous paper the writer ${ }^{2}$ reported that the pinealectomized chickens and pullet grow more rapidly than controls and show an earlier development of the sexual organs. Thus its glandular nature is recognized, and experimental studies and clinical observations lead to the conclusion that the epiphysis plays an important biological function up to the time of puberty.

The present investigation was undertaken in the hope of throwing further light upon the function of the pineal body, being carried on in the Anatomical Laboratory of the Okayama Medical School. In this connection the writer desire to extend his grateful thanks to Profs. Kosaka and Yagita for their kind instructions.

\section{Material and Technique.}

In all, one hundred and five chickens were employed in this study. Eighty chickens were subjected to pinealectomy and the other twentyfive were used for comparison. The chickens, when operated, varied in age from 25 to 42 days. Particular care was taken in this experiment to select experimental and control animals from chickens of the same age; the chickens being hatched on the same day, of eggs obtained from the same hen. The operation was conducted as described in the writer's

1) Broxdi, G., Zeitschr. f. d. ges. Neurol. u. Psychiat., Bd. 9, 1912.

Ilunng, P., Centralbl. d. exper. Med., Bd. 1, 1912, etc.

2) IzAwa, Y., Okayama Igakkai Zassi No. 30, 1923. 
previous paper.* On the control animals only control trepanations were made.

\section{Obscrations after the Operation.}

Many chickens died after the operation. This high mortality is probably due to the fact that the chickens were operated on at so early in age and that the operation on them was so severe, with the inevitable intracranial haemorrage. The experimental and the control animals were kept in separate flocks and fed under identical conditions. During the few weeks after the operation great care was taken with the experimental animals. Although in fair flesh, the birds did not seem in the best of health. Growth rate of pinealectomized chickens was generally slower than that of the controls for several weeks after the operation. Sixteen chickens survived the operation but only eleven of these lived until the time of killing.

Grozeth ratt: : On being compared with the control animals the pinealectomized animals began to grow more rapidly than controls from $\mathrm{Ca} .30$ days after the operation. When sacrificed, a very noticeable difference was observed in body weight of the experimental and control animals. As shown in table 1 , the average weight of experimental animals at the time of the operation was similar to that of the controls, but when autopsied the pinealectomized chickens were considerably heavier than controls.

Crozving: Pinealectomized cocks crowed earlier than codtrols, as will be seen in the accompanying table, the control cocks of cases $1,2,3,4$.

* The operation was conducted after taking careful aseptic precautions, so that no infection occurred. The animal was wrapped with sterile gauze, and after shaving and making an application of iodine tincture, the skin on the posterior end of the skull was cut along the median line. Then the bone was so far removed as to allow the exposure of the posterior portion of the superior longitudinar sinus, where the two lateral sinuses join. After a transverse section of this portion of the sinus had been made by means of small scissors, without lingtins it, the under stump of the sinus wall was drawn out, so as to make the gland fully. exposed. This was grasped firmly with a small pair of forcep and gently pulied out, sufficent caution being taken so as not to snap it in two but to remove it whole. 
did not crow until sacrificed while the pinealectomized animal of the same case crowed prematurely.

Sexual instinct: Operated cocks were observed treading the hen at an early age, from 35 to 50 days before their controls. Control cocks which tread the hen at an early age, are rare, and only one instance has come under my personal observation.

Spurs: Some of the pinealectomized cocks had better developed spurs than controls, while, in others, no well marked differences between the operated and control animals were noted.

Comb and Wattles: As clearly seen in the accompanying table and in photograph, all the operated cocks had well developed, larger comb and wattles than the controls.

Plumage: As a rule, in the male, the dorsal feathers are long and pointed while about one third of the feathers is without habules thus producing the glistening appearance, characteristic of the male, and in the female the dorsal feathers have rounded ends, are relatively short and possess habules along nearly the entire length of the barbs.

As pointed out above, all the pinealectomized cocks showed the premature development of comb and wattles, and when comb and wattles began to develop, hackle feathers and dorsal feathers produced the glistening appearance and the tail feathers became long. Glistening dorsal feathers and long tail feathers $i$. e. the adult plumage, came in earlier in favour of the pinealectomized cocks, This is clearly shown in the photograph.

The age at which the various pairs of experimental and control chickens were autopsied varied from 197 days to 285 days. Each pair was killed at the same time, and the organs were carefuly removed, after weighing, and placed in formalin. After embedding in paraffin, sections were stained with haematoxylin eosin.

\section{Autoptic findings and histological examinations.}

Sexual organs: In the pinealectomized cocks testes showed most remarkable development. Total weight of the testes of the experimental 
animals was $51.0 \mathrm{G}$. against $4.96 \mathrm{G}$. total for the controls, and again, the average weight of the testes of the experimental cocks was $6.37 \mathrm{G}$. while that of the controls was $0.62 \mathrm{G}$.

Viewed microscopically, the seminiferous tubules of the testes of the operated cocks were noticeably dilated and contained several layers of epithelium cells showing all stages of spermatogenesis, while, on the other hand, those of the controls remained small and allmost filled with a few layers of not yet differentiated cells. The most remarkable differences are given in figs. 15, 16 Concerning the interstitial cells of the testes, they seemed increased in number in favour of the pinealectomized animals.

Epidydimiclis: Epidydimidis of the operated cocks gained more in weight and in size than those of the controls. Seen microscopically, the efferent tubules and the ducts of epidydimidis were markedly well developed whit: those of the controls were small and lining epithelium cells were of undifferentiated type. (figs. 19, 20).

Ductus difirins: With regard to the ductus deferens well marked developnent took place in favour of the pinealectomized animals; well dilated lumen being filled with immense spermatozoa. Ductus deferens of the controls were noticeably small and no traces of spermatozoa in the lumen were found. (figs. 21, 22).

Oidry: Ovaries of the pinealectomized hens were considerably heavier than those of the controls. This is clearly shown in the accompaning photograph. (figs. 10, 11, 12). Average weight of the ovary of the operated hen was $7.13 \mathrm{G}$. while that of the control was $1.84 \mathrm{G}$. Well developed oocytes made projection over the surface of the ovary while the same organ in the controls had no such well developed follicles, the largest being less than 200 micron in diameter. Hen of case 11 was allowed to live 285 days, a much longer period than others, so as to note the date of its first laying. The pinealectomized hen first laid at an age of 195 days, while the control did not lay at all.

A carcful study of the ovary of the hen which had been actively laying, showed the following structure: the yolk in different stages of development, atretic follicles or degenerating eggs of different sizes, the discharged follicle in various stage of regression, luteal cells and interstitial 
cells. With regard to the interstitial cells of the ovary, these seemed increased in number in the each pinealectomized animal. (fig. 17).

Fallopian tube: Oviduct of the experimental hen was considerably larger and the ampullary voluminous under portion was well contrasted with the slender upper portion; while, on the other hand, the same tube in the control was short and slender throughout its whole length. (figs. $10,11,12)$.

Hypophysis: In birds the hypophysis is composed of two distinct different portions i. e. anterior lobe and posterior lobe. Intermediate portion is not sharply marked off from the two distinct other parts as in mammals. Anterior lobe is composed of trabecular masses of epithelium cells with numerous sinus-like capillaries between them. The capillaries come into very close relation with the cells, which appear in section as if set around the capillaries. The cells are of three kinds, acidophil cell, chief cell and basophilic cell. These cells represent different conditions of a single kind of cells, since intermediate appearances are also observed. Trabecular acini, formed by trabecular masses of epithelium cells, often enclose colloid substances as in the thyroid.

The pituitary bodies of the experimental animals showed slight increase in absolute weight and decrease in relative weight.

In case of the pinealectomized animals, the above mentioned cells were found densely and numerous basophylic cells also were present in the middle part of the anterior lobe, and eosinophil cells were also slightly increased in number. The most noticeable finding was that the chief cells and one sort of clear cells, were abundantly present in both posterior and under part of the anterior lobe.

In the case of the controls, the cells of the anterior lobe were fewer by far than in that of the experimental animals.

Eyeballs: On compareing the weight of eyeball, it appeared slightly heavier in the pinealectomized groups, although in these, with heavier body wejght, the eyeballs would be expected to be relatively lighter.

Brain: No noticeable differences were noted in the brain weight of two groups.

Langs : Differences of lung weight were conflicting, some of the pineal- 
ectomized animals being superior in weight to the controls, while in others the contrul outstripped the animals subjected to pinealectomy,

Heart: Heart was heavier in favour of the pinealectomized animals.

Alincutary tractus: On comparing the alimentary canal (empty stomach, intestine, plus mesentery), it appeared heavier in the operated animals than in the controls.

Lifor: Pinealectomized animals showed a considerable gain in weight over the controls; but histologically, no differences were to be seen.

Pancreas: A slight increase in weight was present in the operated animals.

Thymus: On taking the table 1 , it is apparent that the weight of the thymus of pinealectomized chicken is heavier than that of the controls, but the reverse seems to occur in the case 2 , in which the control outstripped the experimental animals. Histogically too the thymus showed no appearnce of degeneration, we have, therefore, concluded that the organ may be functionally active.

Splcen: As shown in table 1 pinealectomized chicken had considerable larger spleen than control.

Suprarenal bodics: There is a slight gain in weight in favour of the pinealectomized animals. The average weight of this in each experimental animal was $0.231 \mathrm{G}$. while those of the controls was $0.177 \mathrm{G}$. On slides, diameters of cortex cellcolumn and of trabecule of medullar cells were measured, to know which of them were hypertrophied. Measurement was conducted on 20 spots on the periphery as well as on the center. As shown in the accompaning table the operated chicken had a slightly larger cellcolumn. A careful study of the suprarenal capsule showed on traces of mitotic figures of the nucleus of the cortexcells, and similar arrangement of the cells was found in operated as well as in control animals.

Parathyroidia: There were little or no differences to be seen in the pinealectomized and control animals.

Thyroidia: Data for absolute weight of thyroidea are found for males and females are given in table 1 . The thyroidea appeared slightly heavier in the average of the pinealectomized animals. Diameters of vesicles 
were measured and this gives the following facts.

\begin{tabular}{|c|c|c|c|}
\hline & & Pinealectomized. & Control. \\
\hline \multirow{2}{*}{ 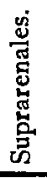 } & $\begin{array}{l}\text { Diameter of cortex cell column } \\
\text { in micron (average) }\end{array}$ & 58.2 & 46.0 \\
\hline & $\begin{array}{l}\text { Diameter of medullar cell trabecule } \\
\text { in micron (average) }\end{array}$ & 56.1 & 43.2 \\
\hline \multirow{2}{*}{ 总 } & $\begin{array}{l}\text { Diameter of medium sized vesicle } \\
\text { in micron (averge) }\end{array}$ & 167 & 146.5 \\
\hline & $\begin{array}{l}\text { Diameter of largest vesicle } \\
\text { in micron (average) }\end{array}$ & 89.6 & 76.9 \\
\hline
\end{tabular}

Bursa Fabricii: The bursa of pinealectomized chicken gained considerable decrease in weight and in size and became atrophied, in the case 5,8 the bursa showed appearance of total regression. Contrary to that, the control's bursa was well developed and showed no sigh of involution.

Bone: Roentgen ray examination showed cancellous structure and compact substance appear similar in both experimental and control animals.

Historical: The writer shall here deal exclusively with observation on the physiology of the pineal body, and shall omit all considerations of the work done upon its structure.

In order to know the function of the pineal body, three methods have always been employed; namely, injection of pineal extract. oral administration of pineal substance and extirpation of the gland.

PRIOR $^{1}$ injected pineal extract into young rabbits. BOEHM ${ }^{2}$ studied the effect of oral administration of pineal substance to young guinea-pigs and rats.

In 1916 Hopkins $^{3}$ fed pineal substance to albinorats. They all recorded that the pineal feeding produces no apparent changes in wtight of body or organs as compared with the controls. Accordig to DANA-BERKLEY ${ }^{4}$ as well as MC. CORD ${ }^{5}$ a prolonged administration caused a relatively rapid

1) Priore, N. Del, Arch. ital. de Biol,; T. 63, 1915.

2) BоEнм. Cited from Horrax.

3) Hopkins, E. R., Jour. exper. Zoo. Vol, 21, 1916.

4) Dana-Berkley, (N. Y.) Med. Rec. Vol. 83, 1913.

5) Mc. Cord, C. P., Jour. Am. med. Assoc. Vol. 63, 65, 1914, 1915. 
growth of the animals subjected to the experiments. Sexual precocity was also noted by Mc. CORD.

In 1909 HowelL $L^{1}$ first reportcd that the effect of intravenous injection of extract of pineal upon the blood pressure is inconstant. Injection of pineal substance by VoN Cros ${ }^{2}$ brought about slight tachycardia with small doses, bradycardia together with pulsus bigenimus or pulsus trigeminus with high doses. He also found that injection of salt produce analogous results, and further that electrical stimulation on rabbits' pineal causes a contraction of the gland with movement in the cerebrospinal fluid in the third ventricle. Finally he claimed that the pineal gland plays a role in preserving certain inorganic substances as organic compounds, and that moreover it regulates the flow of cerebrospinal fluid in the third ventricle. Dixon and Halliburtox ${ }^{3}$ injected extract of sheep pineal but wite negative results as regards blood pressure, heart beat, respiration as well as the urine secretion. JORDAN and EYSTER ${ }^{4}$ studied the effect of injection of pineal extract. Intestinalvasodilatation, glycosuria and transient diuresis were noted by them.

Otтo and Scorts observed an increase in lidney secretion and on the volums of the kidney after injection of pineal extarct. Recently HORrax $^{6}$ stated that the injection of small amounts gave practically on results while with large doses a constant fall in blood pressure and slowing or stoppage of the flow of cerebrospinal fluid were noted.

Although no serious effects were obtained in the animals subjected to the feeding experiment or to the intravenous injection of the pineal extract, pinealoctomy has brought about remarkable results.

In $1910 \mathrm{BIEDL}^{7}$ reported that the pinealectomized puppies show no changes as compared from the controls. To determine tho results of experimental removal of the pineal gland Exier and BoEsse ${ }^{s}$ attempted

1) Howell, W. H., Jour. Exp. Med., Vol. 3.

2) Crox, E. V., Arch. f. d. ges. Physiol. Bd. @8, 1!10?.

3) Dixom, W. E. and Halliburton, W. D., Quart. Jour. Erper. Physiol. Vol. 20, 1909,

1) Jorin, H. E. a. Eyster, J. E., Am. Jour. Pnysiol., Vol. 29, 1911.

i) O'To, I. and Scorr, T. C., Month. Cyclop. and med. Bull., p. $20 \%, 1912$.

(i) Horkax, G., Arch, inter, Med., Vol. 1\%, 1916.

7) BicDI, A., Innere Sekretion 2te Auf. 1913.

b) Exxik, A., and Boesse, T., Neurol. Centralbl., p. 7it, 1:10. 
pinealectomy in young rabbits but with unsatisfactory results. They operated 97 young rabbits and only 6 ( 3 males ane 3 females) survived for any length of time, no differences were observed in the operated and the control animals. They gave the following conclusion: the animal is able to survive, if able to tide over the first one day after the operation but these show no apparent changes as compared with the controls. FOA ${ }^{1}$ was the first who recorded remarkable results after the removal of the glands. He was able with success to extirpate the pineal body in chickens. Fifteen survivors of his series lived to their maturity (13 females \& 2 males). The pinealectomized cocks crowed earlier, gave evidence of sexual instinct prematurely and showed noticeable hypertrophy of combs and and testes. On the contrary no changes were noted in the cese of hens. The following year $^{2}$ he attempted pinealectomy and obtained results confirmatory of his earlier work. He suceeeded with chickens (2 males and 5 females) and with young rats (3 males and 1 female). One rat of his rat series gained an increse in weight of testes greater than that of the controls. No apparent changes in favour of the pinealectomized animals were noted in the other endocrine glands. SARTESCHI ${ }^{3}$ also succeeded in getting positive results after pinealectony. Guinea-pigs, in which the experimental removal of the pineal gland were made, revealed an increase in body weight and in the size of the testes but no change in the other endocrine glands. ZoIA ${ }^{4}$ experimented with pinealectomized chickens. His results were, on the whole, in accord with FoA's. In 1916 Horrax ${ }^{5}$ obtained remarkable results after pinealectomy in many guinea-pigs and rats. The pinealectomized male guinea-pigs gained a slightly heavier body weight and with regard to the genital organs showed a much more noticeable development. Total weight of the testes of the experimental animals was $12815 \mathrm{Mg}$. against $9950 \mathrm{Mg}$. total for the controls, and again, an average of $854.3 \mathrm{Mg}$. for each experimental pig against $663.3 \mathrm{Mg}$, average

1) Fod, C., Arch. ital. de Biol., T. 57, 1912.

2) Loc. Cit. T. 61, 1914 .

3) Sarteschi, U., Pathologica, p. 707, 1913.

4) Zoia, C., Centralbl. f. all. Path. u. path. Anat., Bd. 25, 1914.

5) Loc. cit. 
of each control. Pinealectomized pigs showed an increase in the size of the seminal vesicles over those of the controls, Microscopically the testes of the operated animals showed active spermatogenesis while those of the controls were immatuse in type. Interstitial cells were abundant in favour of the pineylectomized animals. Pinealectomized female pigs were delivered of their young ten days or more before either of their control gave birth, the earieest of the experimental ones bcing deivered three weeks before thier controls. IZAWA ${ }^{1}$ recorded that pinealectomy is possible in chickens. He employed 36 chickens for extirpation of the pineal and anothsr 11 chickens were used for comparison. Four chickens only survived for any length of time.

In the cock that survived, having the pineal body completely removed, rapid development of the comb and testes, premature crow and bodily over growth were especially noticeable. Pinealectomized hen showed more remarkable development of ovary and of oviduct than control.

\section{Discussion.}

With respect to the male chickens the author's results accord with those of $\mathrm{FOA}^{2}$ and $\mathrm{ZOIA}^{3}$ exactly; but concerning the female chickens the writer was the first who found with success that the pullet subjected to pinealectomy show an earlier develoment of sexual organs. In the present investigation three pinealectomized hens again revealed remarkable results. They were all heaviar than controls, showed an considerable increase in weight and in the size of the ovary and of fallopian tube.

In order to note the first laying the operated hens were kept alive a relatively long time. The one lived 164 days, the second lived 220 days and the third lived 285 days. The former two hens were autopsied together with the controls before laying. The third hen laid an egg for
1) Loc. itit.
2) Loc. cit.
3) Loc. cit. 
the first time at 161 days after the operation while the control did not lay at all. It will be seen, in above case at least, the normal period for the pinealectomized hen to reach sexual maturity was shortened and this leaves no possible doubt that the loss of the pineal body stimulates the development of the sexual apparatus in young females as well as in males.

Concerning the other ductless glands nomention has ever been made by other investigators. The possidility of changes in the endocrine organ is to be expected, since the hypophysis, thymus, thyroidea, adrenales, etc. from an interlacing chain of interdependent relationships, and disturbance in the function of any one may throw the equilibrium of all out of balance. Care was taken in this experiment to study the organs of internal secretion microscopically as well as macroscopically.

The only other intracranial organ which is known to have influence upon body over growth and sexual development is the pituitary dody.

Apinealism-loss of the pineal body-is in general associated hyperpituitarism, for an antagonistic regulatory functional relationship is accepted between them. As pointed out above, true chromophobe cells-probably functional phases of acidophil and basophil cell-were present more abundantly in the anterior lobe of the operated chicken, so the organ of this may be more functionally active than that of the controls. It is now stated that the excessive function of the anterior lobe of hypophysis after the time of puberty is attended by acromegalia; while on the other hand that of the pituitary body during prepuberal period is associated with abnormal bodily over-growth. If this is really the case, these findings clearly demonstrate in the case of the pinealectomized chickens the relationship between an increased body weight and the excessive functioning of the pituitary body.

Regarding the sexual organs, operated chickens showed a much greater development than the conntrols. With respect to the interstitial cells of the testes the results coincide with those of Fò conclusively, while concerning the interstitial cells of ovary, many authors have not yet recorded anything. A study of the cytology of interstitial cells of the ovary, 
cacording to Pearl-Boring', reveals the following facts: the cells are round, and scattered throughout the connective tissue, that is, never arranged in a nest together. The nuclei are small and stain intensely; the structure of the cytoplasm is completely obscured by the mass of the granules in the cells, the granules are fairly large in proportion to the size of the cell, and take any acid stain.

The interstitial cells of the ovary of the pinealectomized hen are more numerous than those of the controls.

However, there is a great body of theory concerning the function of the interstitial cells, many authors having attributed to the internal secretion of this cell the function of controlling the development of secondary sex characters. REgAud, Bouin, Mita and HANEs etc. are some of the names who support this theory. Their evidences are based on experimental observations and certain pathological cases where reproductive organs with degenerated germ cells and increased interstitial cells, were coupled with sterility and normal sex behavior. Cileecs ${ }^{2}$ called attention to the inter relationship between the interstitial cells and the secondary sex characters; and observed that the interstitial cells first make their appearance in the chick at 30 days after hatching, and this time entirely accord with the appearance of the secondary sex characters,

The essential point to which it is sufficent here to draw attention is that the pinealectomized chickens showed premature development of sex organs and the earlier development of secondary sex characters.

In man, the pineal is a common seat of tumor. Tumor of the human pineal body during childhood is often attended by pineal disorder. Concerning the human pineal body, in about 90 cases reported, of this number 29 occurred before puberty and again 14 of these cases showed pineal disorder. (Ogle, Nighyo, Hijmaxis van den Bergh, Boeha, Gutzeit, Odermatt, Raymond-Cliud, Beiley-Jelliffe, Horrax, Goldzieher, Ta= keya, Holzhauer, Frankl-Hochwart, Oestreich-Slawyk)* Well de-

1) Borinti, A. M., and Pearl, R., Anat. Red., Vol. 13, 1:17.

2) Cilleuls des, Compt. rend. Soc. Biol. Bd. 61, 1912.

* See the writer's previous paper. 
veloped genital organs, abundant pubic and axillary hairs, deep masculine voice and mental progress together with bodily overgrowth are the noticeable symptoms in the records of these cases. In these cases, the pineal body is really injured by the tumor. So it is quite believable that the function of the injured pineal body is disordered, although it is difficult to say whether the gland is functionally more active or less active than normal. we have known, however that physiological involutin of the pineal occurs at the time of puberty; and according to UEMURA ${ }^{1}$ the appearance of degeneration is noticeable already at 4 years of age. As in the above mentioned, there are no cases reported, showing the pineal symptoms, after the time of puberty.

Therefore it appears to be definitely established, from the results of

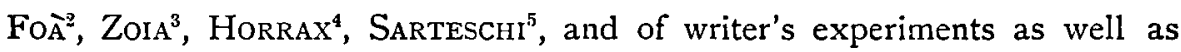
from the known facts of pineal disorder, that sexual precocity would appear only when the pineal body is totally removed, or when the normal products of pineal secretion are inhibited, while at the same time the other ductless gland cannot make compensation for the disturbance of the pineal function. An interesting case of hyperpinealism ${ }^{6}$, which is quoted in the previous writer's paper, revealed remarkable retardation in bodily growth and in development of sex orgens. So it is our impression that the pineal body acts chiefly to inhibit the premature dovelopment of the sex organs, and that pinealectomy tends to hasten normal maturity in young males as well as in young females.

\section{Summary.}

1. Pinealectomy is possible in chicken.

2. Pinealectomized cocks reveal earlier development of the comb and testes,
1) Loc. cit.
2) Loc. cit.
3) Loc. cit.
4) Loc. cit.
5) Loc, cit.
6) Loc. cit. 
with premature crow and more rapid growth, and give earlier evidence of sexual instinct.

3. Pinealectomized hens show premature development of the ovary and oviduct and lay eggs earlier than the controls.

4. Therefore, in the case of the pinealectomized hen, the period to reach sexual maturity is also shortened by far than in the case of the control. 


\section{Explanation of Figures.}

Fig. 1. Showing testes of cocks belonging to case 1 .

Upper : Pinealectomized animal.

Lower: Control.

Fig. 2. Testes of the cocks (case 2).

Upper: Pinealectomized animal.

Lower: Control.

Fig. 3. Testes of cocks of case 3 .

Upper: Those of the pinealectomized animal.

Fig. 4. Testes of cocks (case 4).

Upper : Pinealectomized animal. Lower: Control.

Fig. 5. Testes of cocks belonging to case 5.

Upper : Pinealectomized animal. Lower: Control.

Fig. 6. Testes of cocks (case 6 ).

Upper: Pinealectomized animal. Lower: Control.

Fig. 7. Testes of cocks (case $i$ ).

Upper: Pinealectomized animal. Lower: Conirol.

Fig. 8. Showing testes of cocks belonging to case 8 .

Right: Pinealectomized animal.

Left: Control.

a. Ductus defferens.

Fig. 9. Note larger size of spur in pinealectomized animal (upper photo) belonging to case 6 .

Fig. 10. Sexual organs of hens (case 9).

Left: Those of the pinealectomized hen. Right: Those of the control.
a. ovary.
b. oviduct
c. bursa Fabricii.
d. cloaca

Fig. 11. Sexual organs of hens belonging to case 10 .

Left: Pinealectomized animal.

Right: Control.

Fig. 12. Sexual organs of hens (case 11).

Left : Pinealectomized animal.

Right: Control.

Fig. 13. Cancellous structure and compact substance of bone in control animal (case 5).

Fig. 14. Showing cancellous structure and compact substance of bone in pinealectomized animal (case 5).

Fig. 15. Sections through correponding portion of testes of pinealectomized cock belonging to case 6 .

Note larger size of tubules, active spermatogenesis and numerous interstitial cells.

a. Interstitial cells.

Fig. 16. Sections of testes of control (case 6 ).

Fig. 17. Sections of ovary of pinealectomized hen (case 10).
o. Oocyte.
a. Interstitial cells.

Fig. 18. Sections of ovary of control (case 10). 
Fig. 1\%. Sections of epidydimidis of operated cock (case i).
a. Retc testis.
b. Efferent tulsule
c. Duct of epidydimidis.

d. Ductus defferens; well dileted lumen being filled with immense spermatozoz.

Fig. 20. Sections of epidydimidis of control belonging to case 6 .

Fig. 21. Sections of ductus defferens of oprated cock (casc (i).

Dilated lumen, being filled with immense spermalozoa.

Fig. 2. Those of control (case 6 ).

Fig. 2:i. Sections through corresponding upyer portion of oviduct in pinealectomized animal (case 111 ).

Fig. 21. That of control (case 10).

Fig. 2-. Showing one part of wall of under part of Fallopian tule in pinealectomized hen (case 0 ).

Fig. 21\%. Sections of under part of oviduct in control (case 9).

Fig. 27. Pinealectomized cock (case 8 ), aged $34 \mathrm{k} / 7$ weeks, 244 days after the operation.

Fig. 2s. Control (case $x$ ).

Fig. 2!. Pinealectomized cock (case 3), aged $25 \%$, weeks, 150 days after the operation.

Fig. 30. Control of case 3.

Fig. :1. Pinealectomized cock belonging to case 5, aged :00 weeks, 1,1 days after the operation.

Fig. :i:. Control of the same case.

Fig. :3.;. P'inealecto:uized cock of case 7 , aged $5: ;$ weeks, $2 \times 1$ days after the operation.

Fig. : $:$. Control of case 7 .

Fig. 3. Pinealectomized hen (case 11), aged $405 / 7$ weeks, 231 days after the operation.

Fig. 3i. Control of case 11 .

Fig. :it. Pinealectomized hen belonging to case 10 , aged 31 weeks, 1 liti days after the operation.

Fig. 3s. Control of case 10 . 
Table I.

\begin{tabular}{|c|c|c|c|c|c|c|c|c|c|c|c|c|c|c|c|c|c|c|c|c|c|c|c|}
\hline & & \multicolumn{2}{|c|}{ Case $1(\hat{\partial})$} & \multicolumn{2}{|c|}{ Case $2(\hat{\delta})$} & \multicolumn{2}{|c|}{ Case $3(\hat{\delta})$} & \multicolumn{2}{|c|}{ Case $4(\hat{b})$} & \multicolumn{2}{|c|}{ Case $5(\hat{b})$} & \multicolumn{2}{|c|}{ Case $6(\hat{\delta})$} & \multicolumn{2}{|c|}{ Case $7(\boldsymbol{\beta})$} & \multicolumn{2}{|c|}{ Case $8(\hat{b})$} & \multicolumn{2}{|c|}{ Case 9 (우) } & \multicolumn{2}{|c|}{ Case 10 (우) } & \multicolumn{2}{|c|}{ Case 11 (우) } \\
\hline & & Op'd & Control & Op'd & Control & Op'd & Control & Op'd & Control & Op'd & Control & Op'd & Control & Op'd & Control & Op'd & Control & $\mathrm{OP}^{\prime} \mathrm{d}$ & Control & Op'd & Control & Op'd & Control \\
\hline \multicolumn{2}{|c|}{ Age of animals, at operation, in days. } & 21 & 21 & 21 & 21 & 24 & 24 & 24 & 24 & 30 & 30 & 31 & 31 & 28 & 28 & 28 & 28 & 25 & 25 & 34 & 34 & 34 & 34 \\
\hline \multirow{22}{*}{ 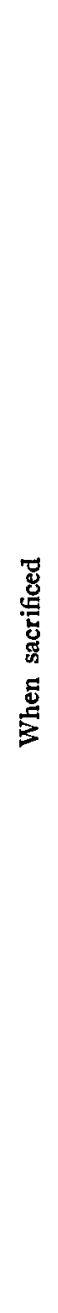 } & Age in days & 195 & 195 & 164 & 164 & 180 & 180 & 205 & 205 & 211 & 211 & 251 & 251 & 246 & 246 & 272 & 272 & 164 & 164 & 220 & 220 & 285 & 285 \\
\hline & $\begin{array}{l}\text { Weight of: } \\
\text { Body }\end{array}$ & $\begin{array}{l}\text { grams. } \\
1000 .\end{array}$ & $\begin{array}{c}\text { grams. } \\
870 .\end{array}$ & $\begin{array}{l}\text { grams. } \\
890 .\end{array}$ & $\begin{array}{l}\text { grams. } \\
630 .\end{array}$ & $\begin{array}{l}\text { grams. } \\
1100 .\end{array}$ & $\begin{array}{c}\text { grians. } \\
954 .\end{array}$ & $\begin{array}{l}\text { grams. } \\
1450 .\end{array}$ & $\begin{array}{l}\text { grams. } \\
1205 .\end{array}$ & $\begin{array}{l}\text { grams. } \\
1650 .\end{array}$ & $\begin{array}{l}\text { grams. } \\
1150 .\end{array}$ & $\begin{array}{l}\text { grams. } \\
1570 .\end{array}$ & $\begin{array}{l}\text { grans. } \\
1230 .\end{array}$ & $\begin{array}{l}\text { grams. } \\
1650 .\end{array}$ & $\begin{array}{l}\text { grams. } \\
1150 .\end{array}$ & $\begin{array}{l}\text { grams. } \\
2005 \text {. }\end{array}$ & $\begin{array}{l}\text { grams. } \\
1700 .\end{array}$ & $\begin{array}{l}\text { grams. } \\
1115 .\end{array}$ & $\begin{array}{c}\text { grams. } \\
810 .\end{array}$ & $\begin{array}{l}\text { grams. } \\
1650 \text {. }\end{array}$ & $\begin{array}{l}\text { grams. } \\
1400 .\end{array}$ & $\begin{array}{l}\text { grams. } \\
1850 .\end{array}$ & $\begin{array}{l}\text { grams. } \\
1660 \text {. }\end{array}$ \\
\hline & Hypophysis & 0.015 & 0.014 & 0.017 & 0.015 & 0.014 & 0.015 & 0.016 & 0.015 & 0.024 & 0.02 & 0.012 & 0.013 & 0.018 & 0.019 & 0.011 & 0.0115 & 0.012 & 0.011 & 0.014 & 0.0105 & 0.013 & 0.011 \\
\hline & Suprarenales & 0.19 & 0.12 & 0.235 & 0.112 & 0.185 & 0.165 & 0.17 & 0.2 & 0.35 & 0.24 & 0.27 & 0.25 & 0.265 & 0.220 & 0.15 & 0.16 & 0.145 & 0.100 & 0.32 & 0.26 & 0.27 & 0.205 \\
\hline & Kidneys & 7.1 & 6.1 & 8.9 & 4.2 & 8.5 & 7.5 & 11.0 & 9.4 & 12.0 & 8.2 & 12.0 & 8.0 & 12.8 & 7.0 & 15.6 & 12.2 & 8.6 & 7.3 & 14.4 & 10.5 & 13.7 & 11.0 \\
\hline & Thyroid & 0.05 & 0.065 & 0.045 & 0.04 & 0.07 & 0.57 & 0.102 & 0.065 & $1.1^{\circ}$ & 0.06 & 0.091 & 0.07 & 0.14 & 0.07 & 0.09 & 0.095 & 0.06 & 0.057 & 0.15 & 0.12 & 0.101 & 0.092 \\
\hline & Para-thyroid & 0.015 & 0.02 & 0.012 & 0.018 & 0.014 & 0.015 & 0.019 & 0.017 & 0.025 & 0.021 & 0.020 & 0.017 & 0.014 & 0.013 & 0.02 & 0.021 & 0.014 & 0.0141 & 0.021 & 0.016 & 0.018 & 0.018 \\
\hline & Thymus & 2.3 & 1.85 & 0.5 & 0.76 & 2.4 & 1.95 & 2.1 & 1.00 & 2.65 & 0.8 & 3.75 & 2.5 & 6.3 & 1.5 & 5.6 & 3.2 & 1.0 & 0.74 & 2.8 & 1.72 & 3.4 & 2.02 \\
\hline & Pancreas & 2.25 & 1.98 & 1.65 & 1.25 & 2.4 & 1.6 & 3.4 & 2.75 & 3.71 & 3.25 & 4.5 & 3.8 & 5.2 & 2.2 & 6.8 & 4.5 & 2.45 & 1.56 & 4.6 & 4.0 & 4.2 & 4.1 \\
\hline & Liber & 34.5 & 35.3 & 42.2 & 21.3 & 40.0 & 32.0 & 45.0 & 35.0 & 47.8 & 39.5 & 46.0 & 31.0 & 45.3 & 32.0 & 52.0 & 41.0 & 44.5 & 24.5 & 48.0 & 36.0 & 51.0 & 46.0 \\
\hline & Spleen & 4.15 & 1.45 & 1.95 & 0.8 & 2.07 & 1.71 & 4.5 & 3.2 & 3.6 & 2.0 & 5.0 & 3.0 & 8.0 & 1.2 & 7.0 & 2.2 & $2.75^{\circ}$ & 1.96 & 3.2 & 1.8 & 5.6 & 2.1 \\
\hline & Alimentary tractus (empty) & 75.0 & 45.0 & 64.0 & 51.0 & 80.0 & 57.0 & 101. & 85.0 & 150.0 & 83.0 & 120.0 & 91.0 & 160.0 & 85. & 180. & 105. & 96. & 51. & 156. & 101. & 148.0 & 150.0 \\
\hline & Brain & 2.85 & 2.7 & 3.25 & 2.7 & 3.1 & 3.1 & 3.26 & 2.9 & 3.35 & 2.2 & 2.9 & 3.5 & 2.7 & $2.7^{\prime}$ & 3.9 & 2.9 & 2.5 & 2.37 & 3.1 & 2.8 & 3.3 & 3.1 \\
\hline & Eyeballs & 4.8 & 4.3 & 5.0 & 5.1 & 5.0 & 5.55 & 4.6 & 4.7 & 5.4 & 5.1 & 5.0 & 5.1 & 5.2 & 5.0 & 6.1 & 6.0 & 4.5 & 4.6 & 5.1 & 5.2 & 4.5 & 5.1 \\
\hline & Testes with Epididymi & 1.3 & 0.4 & 2.0 & 0.19 & 2.8 & 0.34 & 6.6 & 0.85 & 5.5 & 1.04 & 11.0 & 0.2 & 7.8 & 0.7 & 14.2 & 1.29 & - & - & - & - & - & - \\
\hline & Lungs & 6.1 & 9.2 & $9.1^{\circ}$ & 5.85 & 9.1 & 6.3 & 8.8 & 11.0 & 12.0 & 9.0 & 14.6 & 8.91 & 14.5 & 6.5 & 16.0 & 9.0 & 8.1 & 6.2 & 15.0 & 13.0 & 14.0 & 12.0 \\
\hline & Heart & 5.7 & 5.1 & 5.2 & 3.56 & 4.7 & 3.2 & 8.1 & 4.6 & 11.3 & 5.7 & 12.0 & 6.7 & 15.2 & 4.5 & 15.3 & 13.0 & 9.1 & 7.8 & 10.0 & 11.0 & 11.0 & 10.0 \\
\hline & Comb & 5.55 & 2.22 & 9.7 & 1.6 & 8.1 & 2.0 & 11.0 & 2.6 & 7.1 & 1.9 & 15.0 & 4.0 & 12.0 & 1.7 & 17.0 & 5.0 & - & - & - & - & - & - \\
\hline & Wattles & 2.17 & 0.85 & 2.31 & 0.47 & 3.3 & 0.5 & 2.5 & 1.0 & 5.1 & 1.0 & 4.4 & 0.45 & 4.3 & 1.0 & 6.2 & 1.7 & - & - & - & - & - & - \\
\hline & Bursa Fabricii & 0.05 & 0.6 & 0.178 & 0.4 & 0.5 & 1.6 & 3.2 & 1.7 & 0.02 & 0.3 & 1.0 & 2.0 & 0.7 & 1.2 & 0.01 & 0.4 & 0.7 & 1.6 & 0.08 & 0.9 & 0.02 & 0.41 \\
\hline & Ovary & - & - & - & - & - & - & - & - & - & - & - & - & - & - & - & - & 4.3 & 1.5 & 5.1 & 1.02 & 14.0 & 6.3 \\
\hline & $\begin{array}{l}\text { Length of: } \\
\text { Fallopian tube }\end{array}$ & $\mathrm{cm}$ & cm. & $\mathrm{cm}$ & cm. & $\stackrel{c}{-}$ & $\mathrm{cm}$ & cm. & 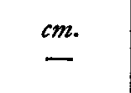 & $\mathrm{cm}$ & $c m$ & $\mathrm{~cm}$. & cm. & cm. & $\mathrm{cm}$ & $c m$. & $\underline{c m}$. & $\begin{array}{l}\mathrm{cm} . \\
17.0\end{array}$ & $\begin{array}{c}c m . \\
9.0\end{array}$ & $\begin{array}{c}\mathrm{cm} . \\
16.5\end{array}$ & $\begin{array}{c}c m . \\
6.0\end{array}$ & $\begin{array}{c}c m . \\
45.0\end{array}$ & ${ }_{21.0}^{c m .0}$ \\
\hline \multicolumn{2}{|c|}{$\begin{array}{l}\text { Age of animals on the day when it } \\
\text { crowed the first time }\end{array}$} & $110^{\circ}$ & * & $?$ & * & 120 & * & 165 & * & 105 & $?$ & 95 & 198 & 150 & 220 & 141 & 240 & & & & & & \\
\hline
\end{tabular}

* It did not crow until sacrificed. 


\section{Plate 1.}

Fig. 1

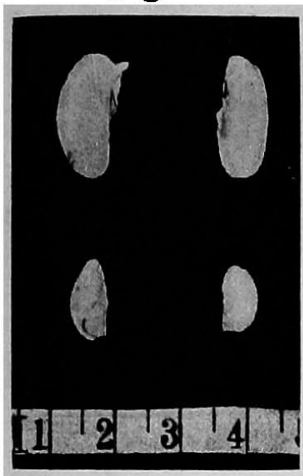

Fig. 2

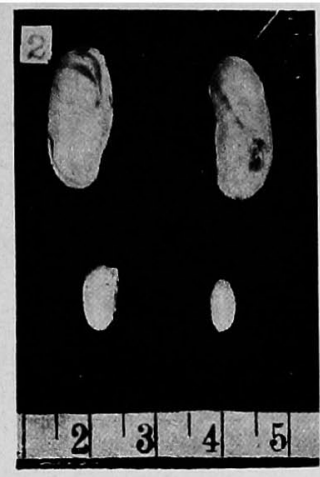

Fig. 3

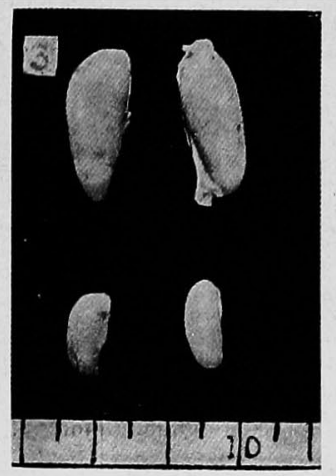

Fig. 4

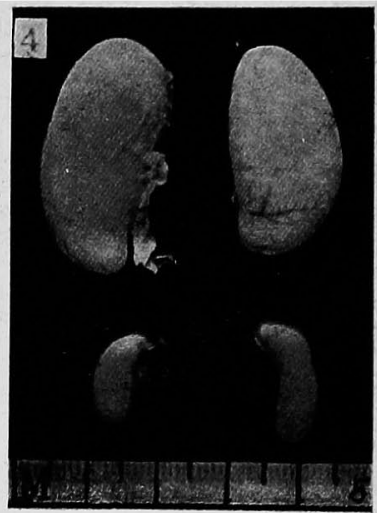

Fig. 5

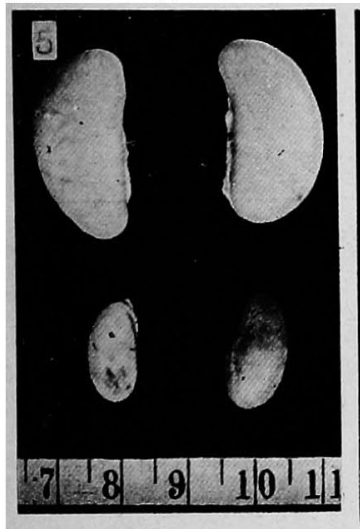

Fig. 6

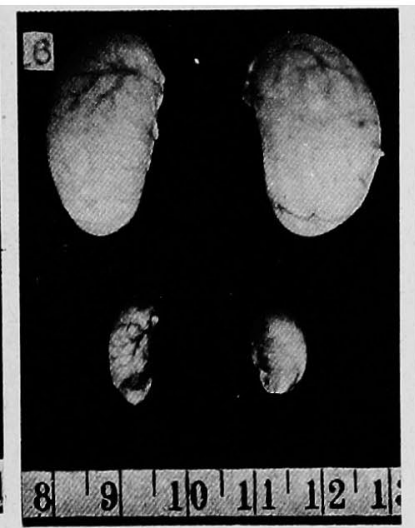

Fig. 8

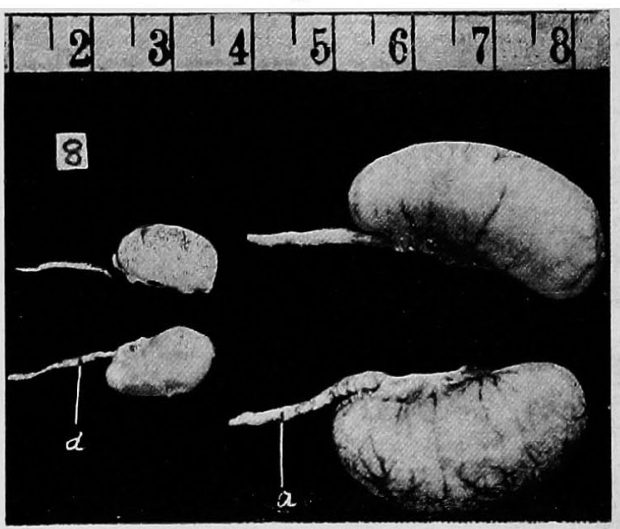

Fig. 9

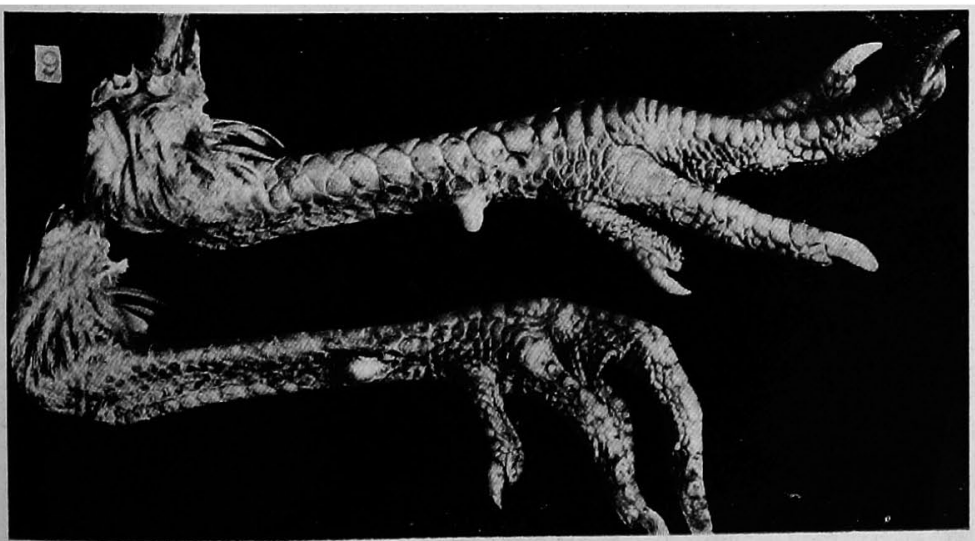

Fig. 7

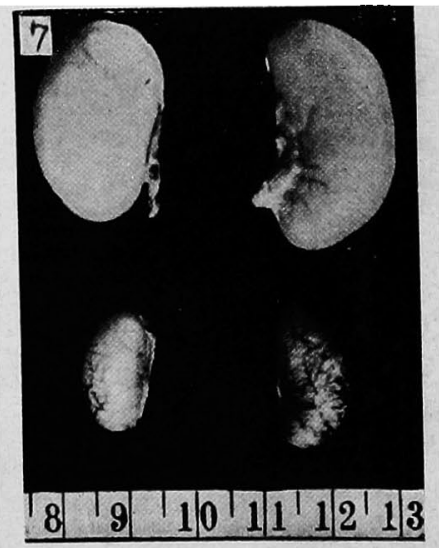


Plate 2.

Fig. 10

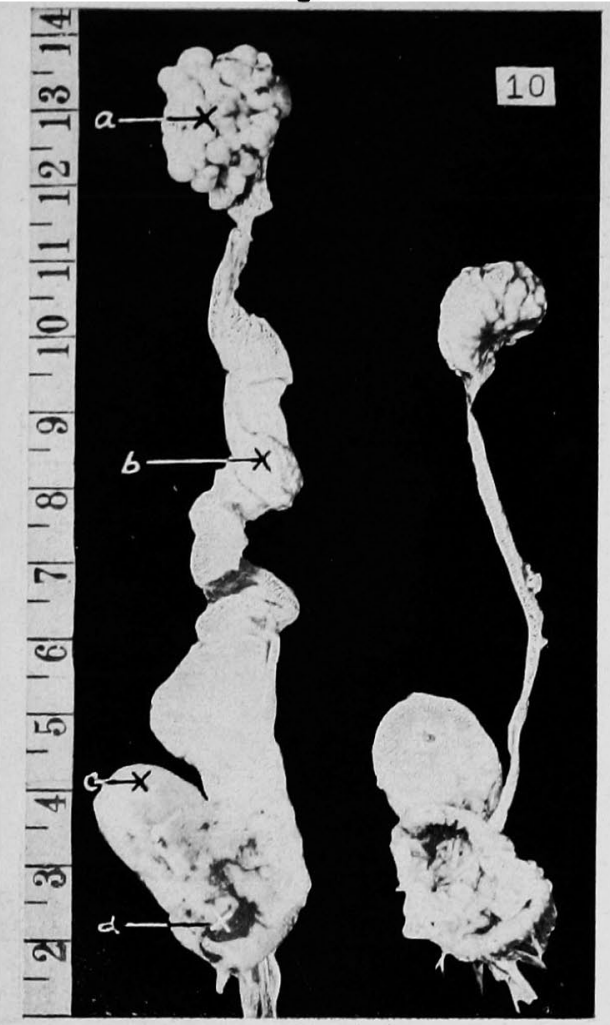

Fig. 12

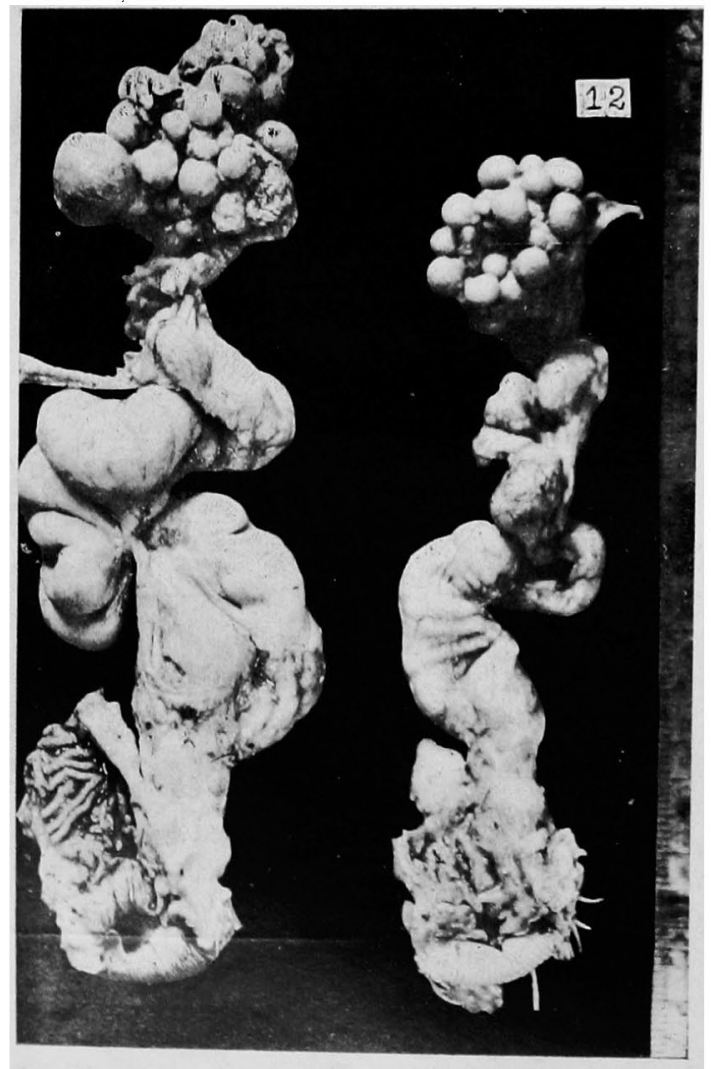

Fig. 11

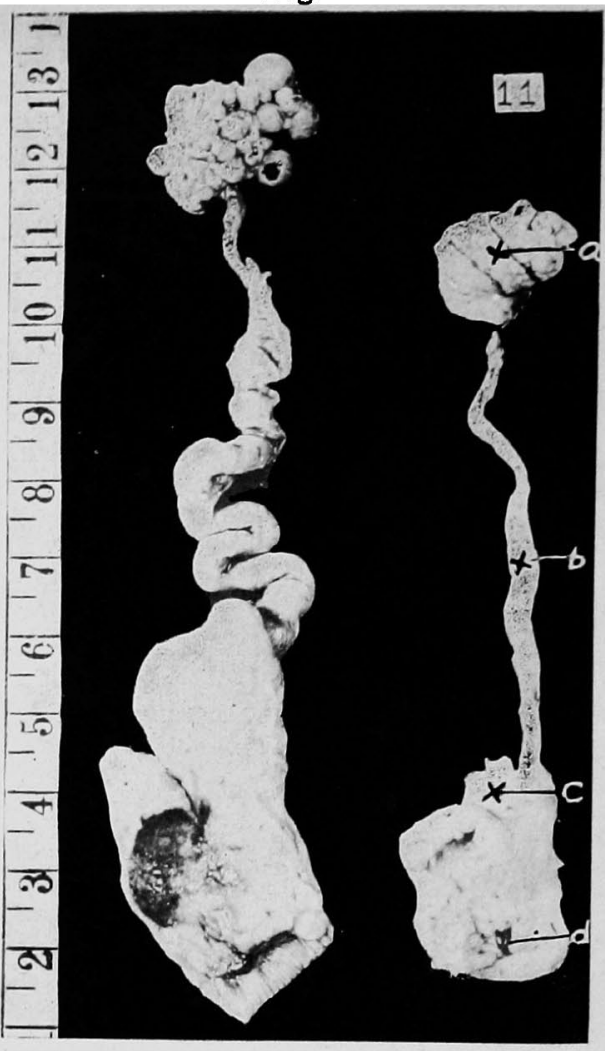

Fig. 13

Fig. 14

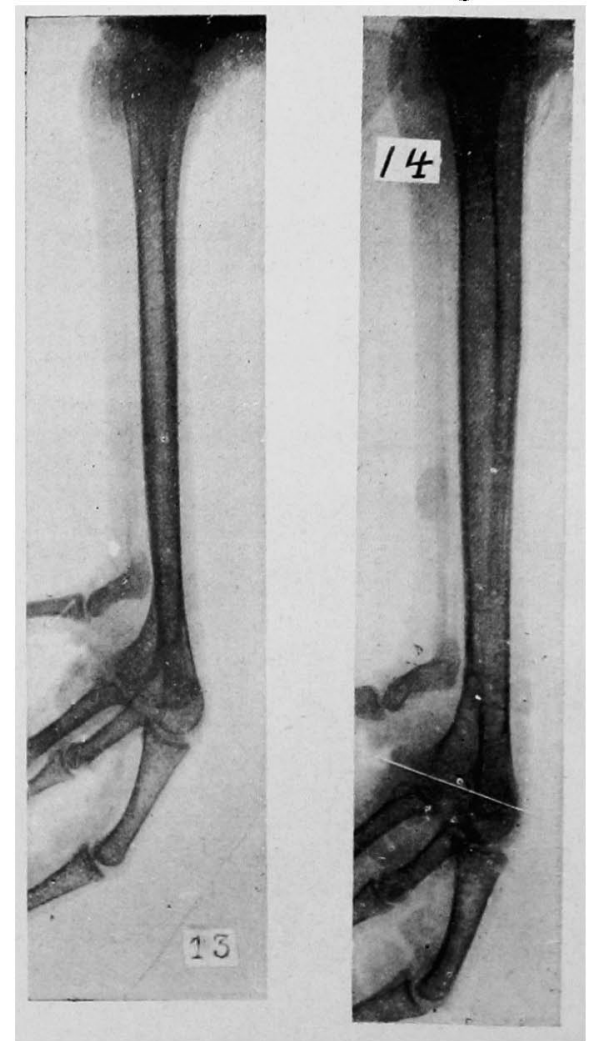


Plate 3.

Fio. 15

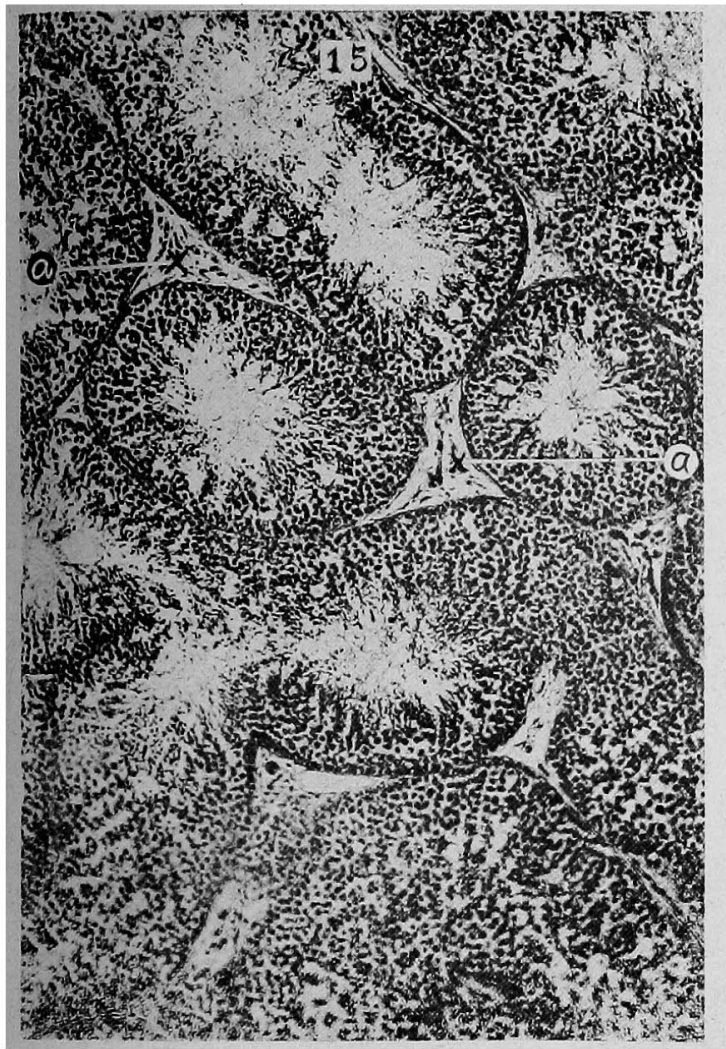

Fig. 16

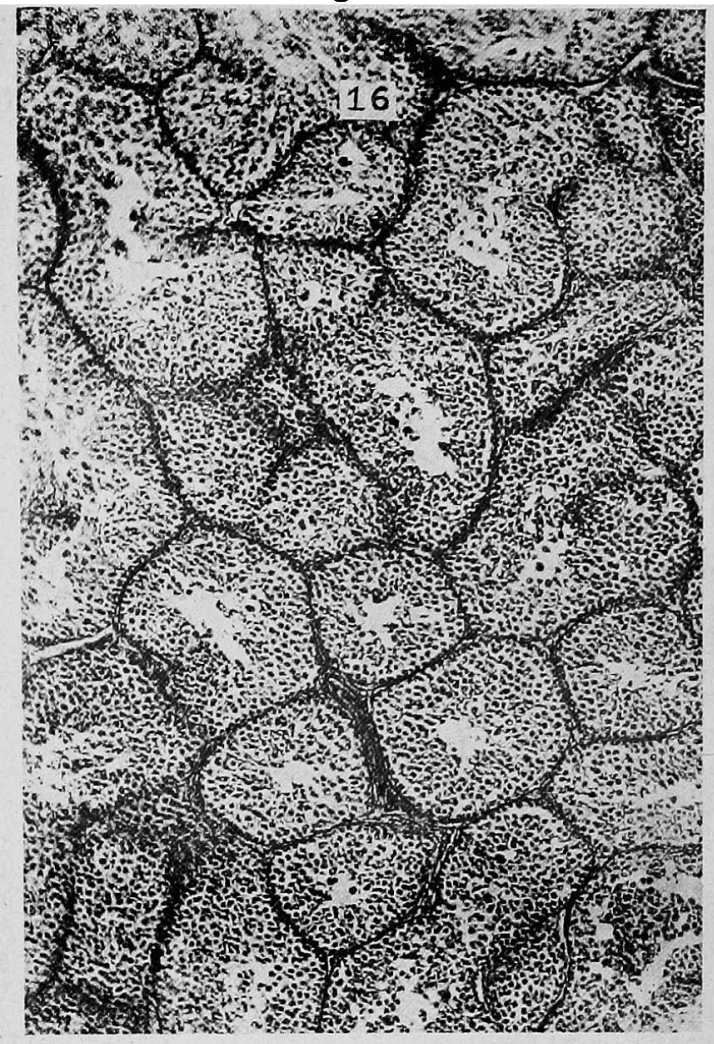

\section{Fig. 17}

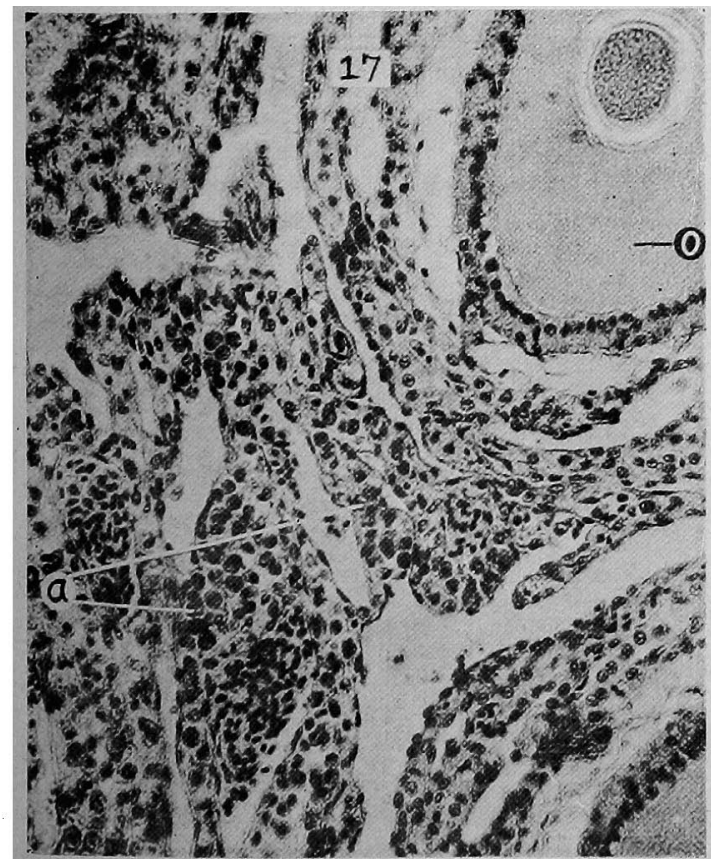

Fig. 18

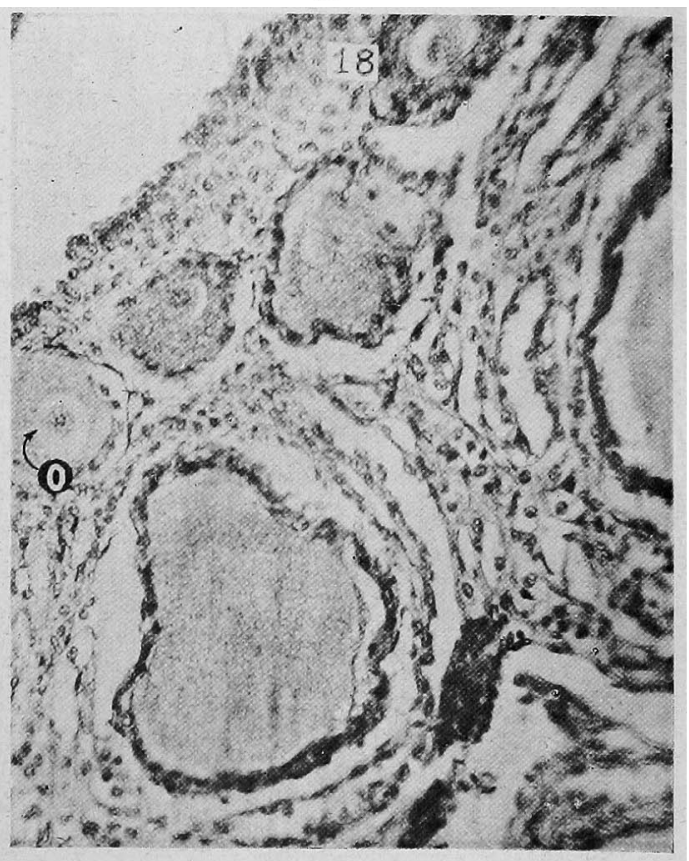


Fig. 19

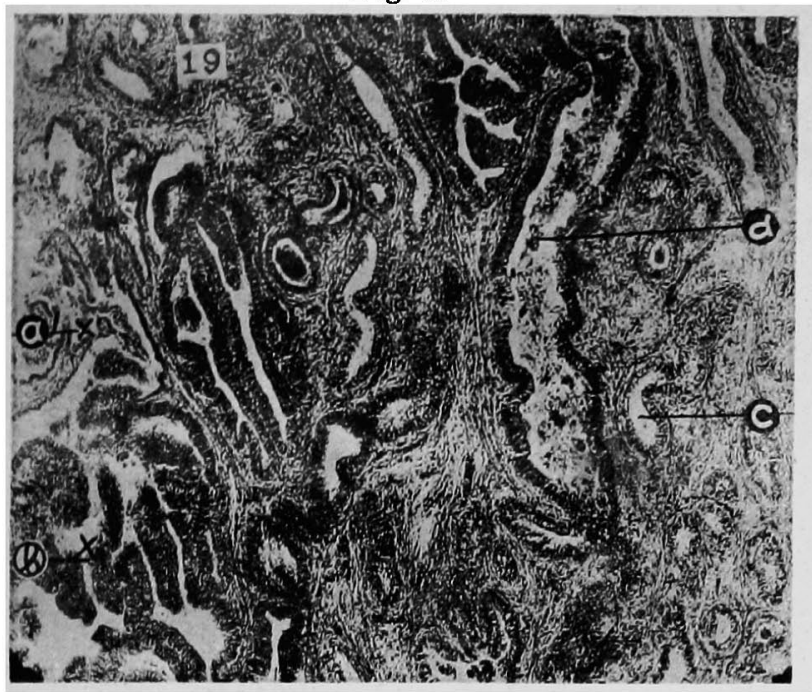

Fig. 21

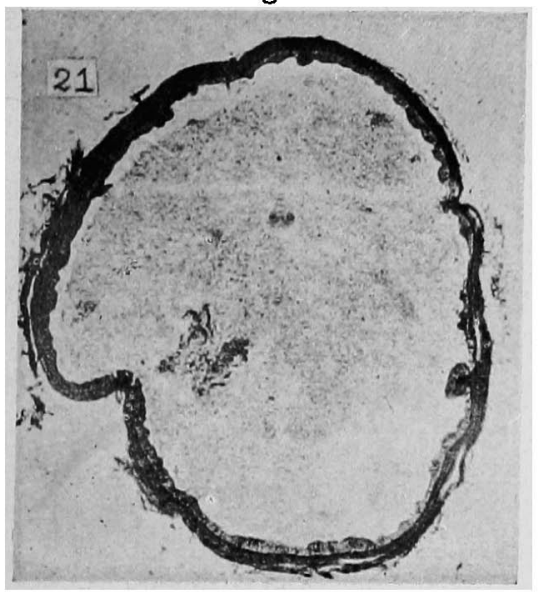

Fig. 25

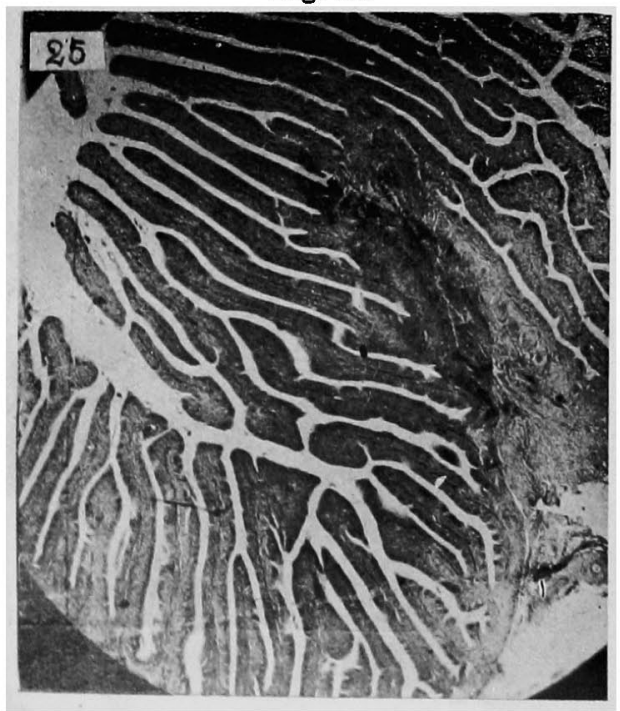

Fig. 20

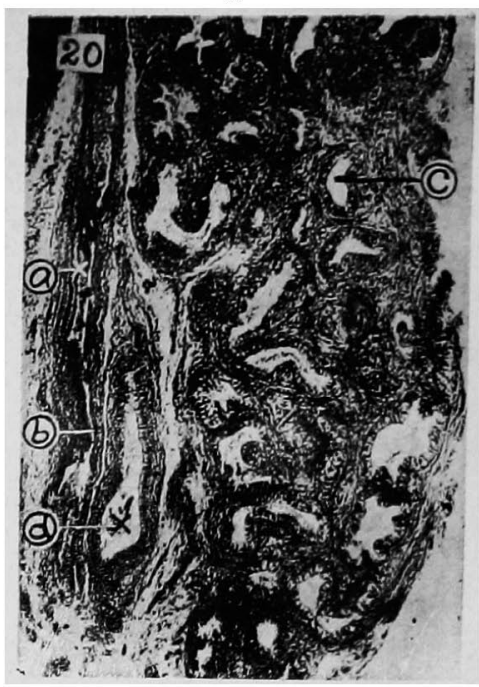

Fig. 23

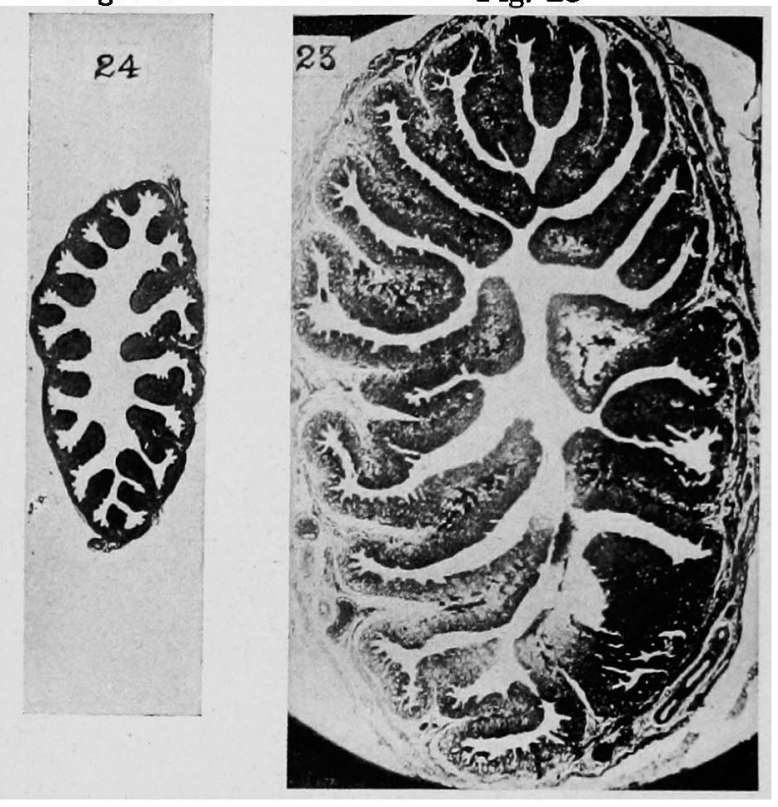

Fig. 22

Fig. 26

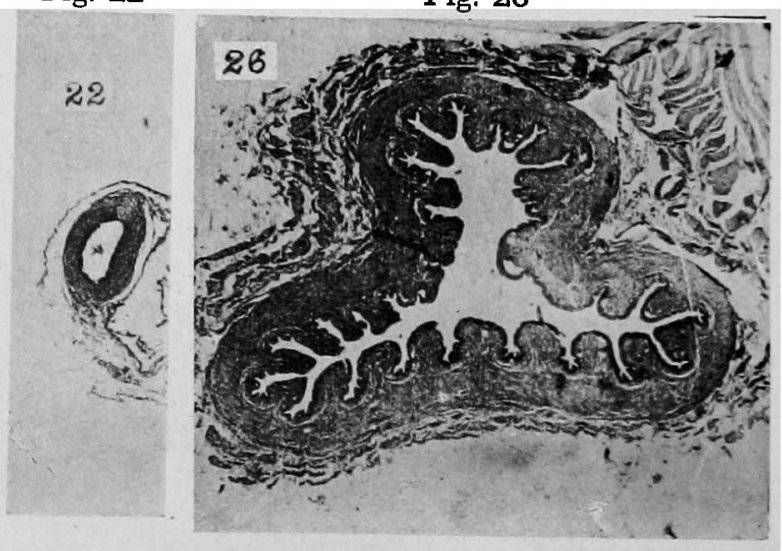




\section{Plate 5.}

Fig. 27

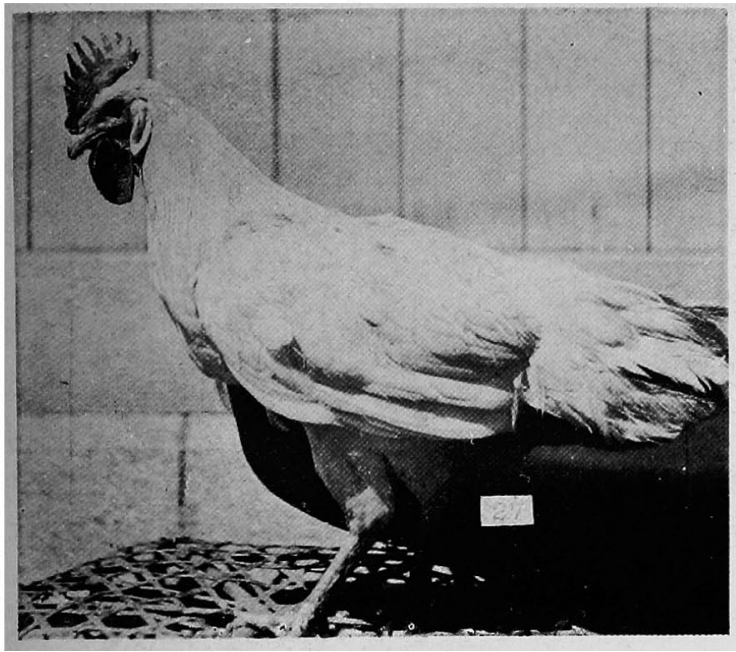

Fig. 29

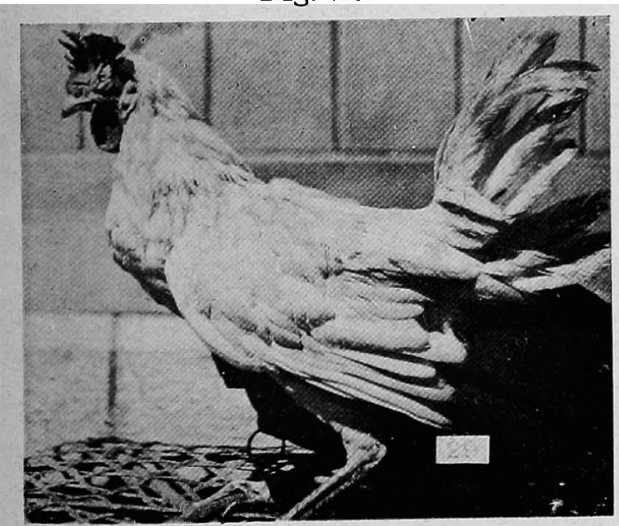

Fig. 31

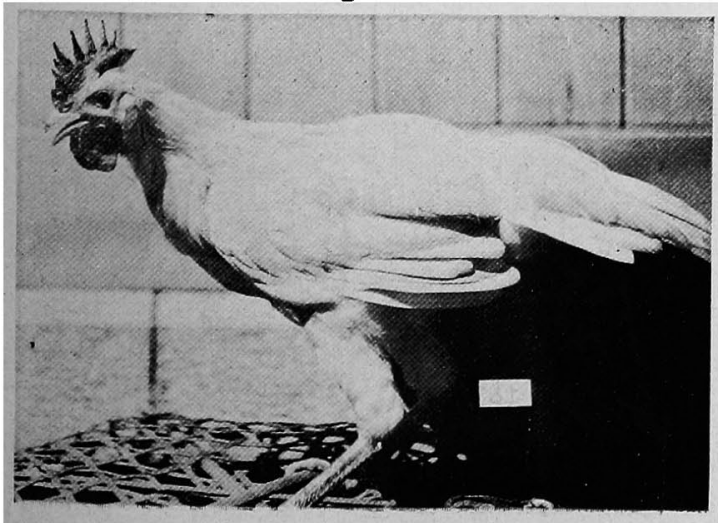

Fig. 28

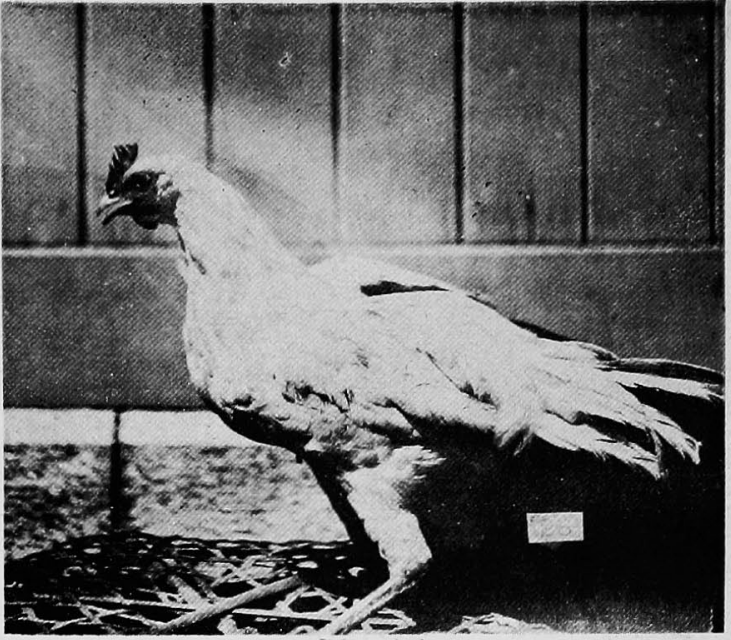

Fig. 30

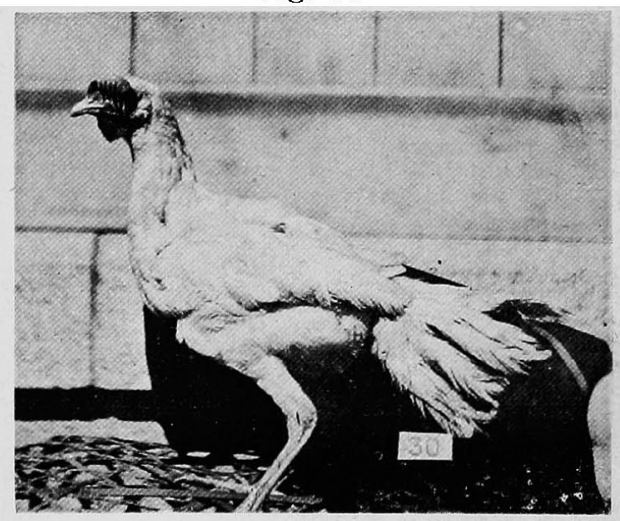

Fig. 32

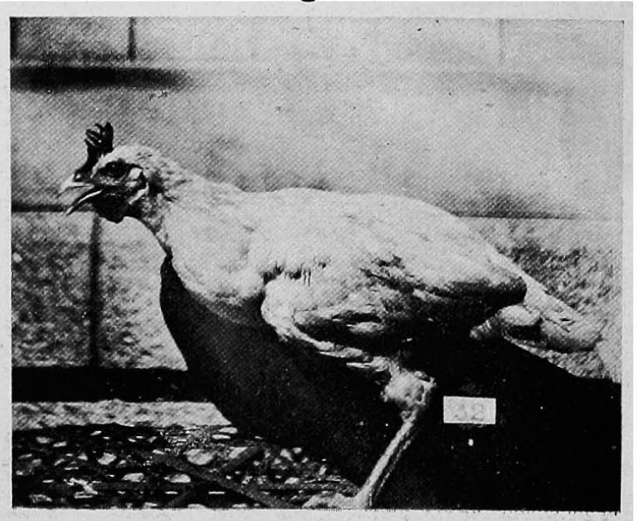


Plate 6.

Fig. 33

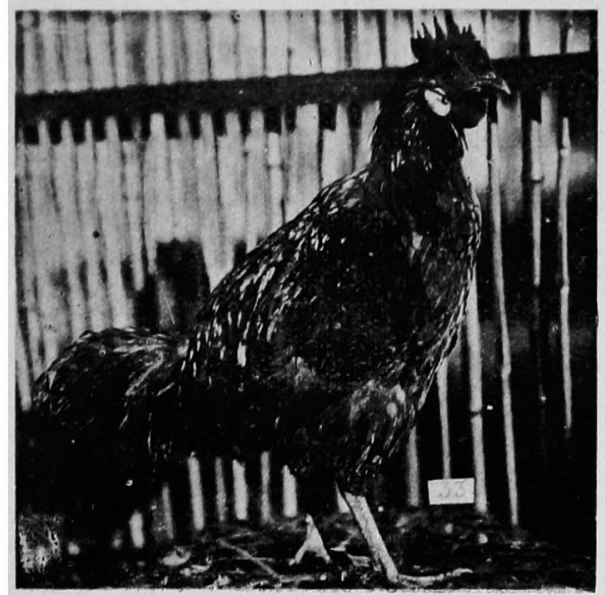

Fig. 34

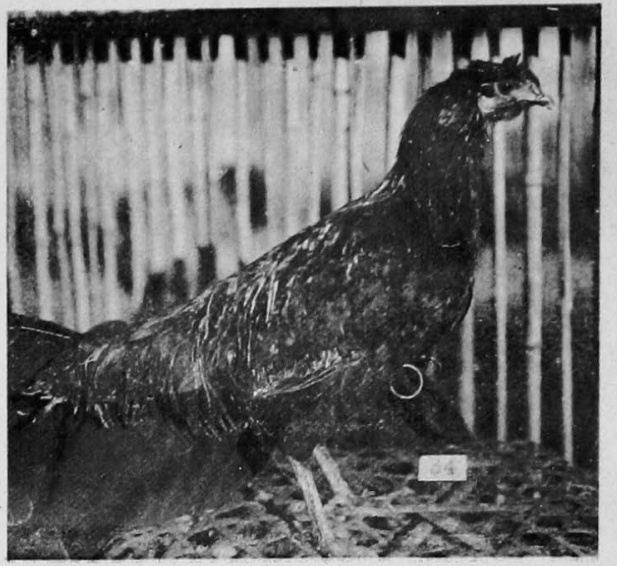

Fig. 35

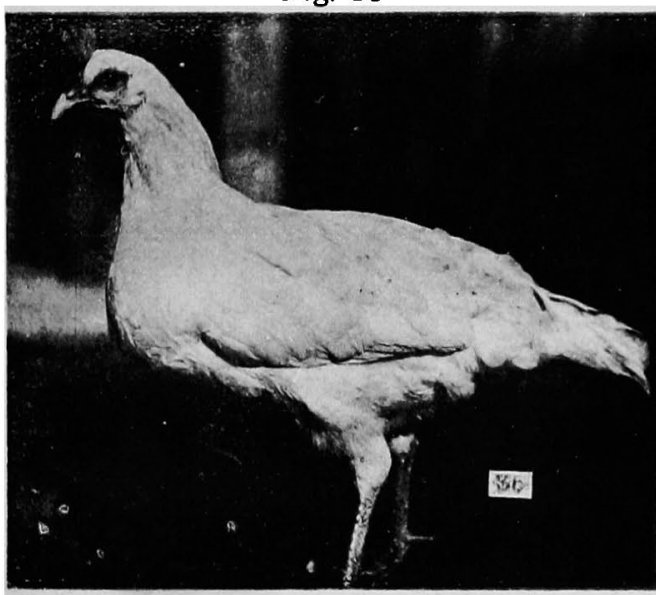

Fig. 37

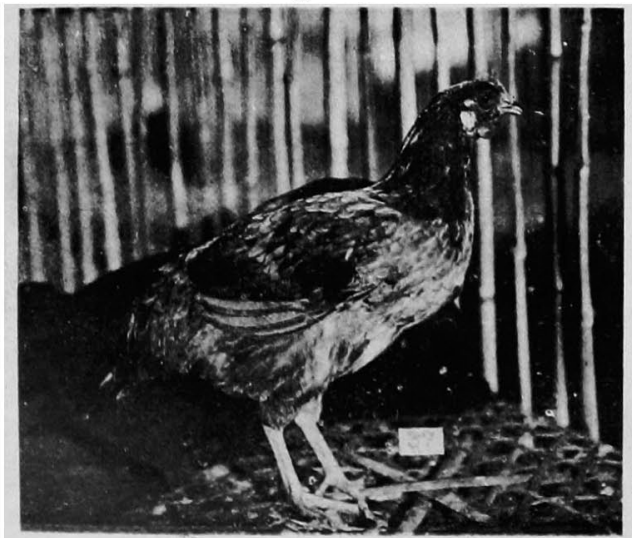

Fig. 36

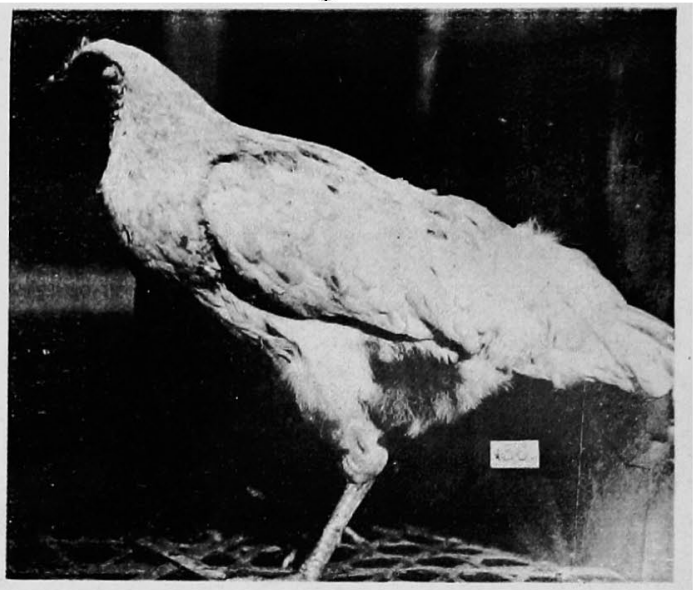

Fig. 38

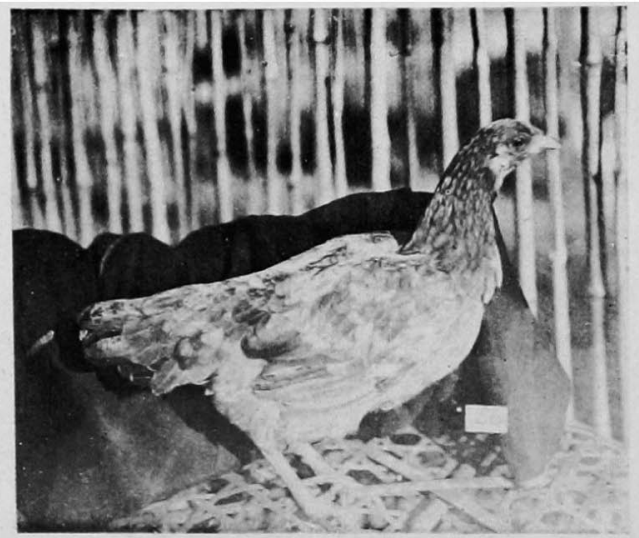

